medRxiv preprint doi: https://doi.org/10.1101/2021.05.19.21257439; this version posted May 22, 2021. The copyright holder for this preprint (which was not certified by peer review) is the author/funder, who has granted medRxiv a license to display the preprint in perpetuity. It is made available under a CC-BY-NC-ND 4.0 International license .

\title{
Rapid And high throughput RT-qPCR assay for identification and differentiation between SARS-CoV-2 variants B.1.1.7 and B.1.351.
}

Oran Erster ${ }^{1 \S}$, Ella Mendelson ${ }^{1,2}$, Virginia Levy ${ }^{1}$, Areej Kabat ${ }^{1}$, Batya Mannasse ${ }^{1}$, Hadar Asraf ${ }^{1}$, Roberto Azar ${ }^{1}$, Yaniv Ali ${ }^{1}$, Rachel Shirazi ${ }^{1}$, Efrat Bucris ${ }^{1}$, Dana Bar-llan ${ }^{1}$, Orna Mor ${ }^{1,2}$, Michal Mandelboim ${ }^{1,2}$, Danit Sofer ${ }^{1}$, Shai Fleishon ${ }^{1}$, Neta S Zukerman ${ }^{1}$

${ }^{1}$ Central Virology Laboratory, Public Health Services, Ministry of Health, Chaim Sheba Medical Center, Ramat Gan, Israel.

${ }^{2}$ School of Public Health, Sackler Faculty of Medicine, Tel-Aviv University, Tel-Aviv, Israel.

${ }^{\S}$ Corresponding author contact information: oran.erster@sheba.health.gov.il

\begin{abstract}
Emerging SARS-CoV-2 (SC-2) variants with increased infectivity and vaccine resistance are of major concern. Rapid identification of such variants is important for the public health activities and provide valuable data for epidemiological and policy decision making. We developed a multiplex quantitative RTqPCR (qPCR) assay that can specifically identify and differentiate between the emerging B.1.1.7 and B.1.351 SC-2 variants. In a single assay, we combined four reactions: one that detects SC-2 RNA independently of the strain, one that detects the D3L mutation, which is specific to variant B.1.1.7, and one that detects the 242-244 deletion, which is specific to variant B.1.351. The fourth reaction identifies human RNAseP gene, serving as an endogenous control for RNA extraction integrity. We show that the strain-specific reactions target mutations that are strongly associated with the target variants, and not with other major known variants. The assay's specificity was tested against a panel of respiratory pathogens ( $n=16)$, showing high specificity towards SC-2 RNA. The assay's sensitivity was assessed using both In-vitro transcribed RNA and clinical samples, and was determined to be between 20 and 40 viral RNA copies per reaction. The assay performance was corroborated with Sanger and whole genome sequencing, showing complete agreement with the sequencing results. The new assay is currently implemented in the routine diagnostic work at the Central Virology Laboratory, and may be used in other laboratories to facilitate the diagnosis of these major worldwide circulating SC-2 variants.
\end{abstract}

NOTE: This preprint reports new research that has not been certified by peer review and should not be used to guide clinical practice. 
medRxiv preprint doi: https://doi.org/10.1101/2021.05.19.21257439; this version posted May 22, 2021. The copyright holder for this preprint (which was not certified by peer review) is the author/funder, who has granted medRxiv a license to display the preprint in perpetuity. It is made available under a CC-BY-NC-ND 4.0 International license .

Keywords: SARS-CoV-2, RT-qPCR, variant B.1.1.7, variant B.1.351, rapid diagnosis, differential PCR, Sanger sequencing, Illumina sequencing

\section{INTRODUCTION}

The recent emergence of new SARS-COV-2 (SC-2) variants of concern (VOC) B.1.1.7 in the UK and B.1.351 in South Africa, both characterized by increased transmissibility and potential vaccine resistance (1-4), prompted dedicated surveillance by Israel's Central Virology Laboratory, to monitor their incursion into Israel.

Since the genome of variant B.1.1.7 contains 23 unique mutations, and that of variant B.1.351 contains 18 unique mutations, compared with the original Wuhan strain, it is practically impossible to detect all of them in one qPCR assay. Thus far, the Thermo Fisher SC-2 detection kit (CAT CCU002, https://www.thermofisher.com) was utilized to identify B.1.1.7 suspected samples (3). One of the reactions in this kit is directed to the viral Spike gene, and is negative when the template sequence contains the 69-70 deletion, which is one of the B.1.1.7 variant mutations. However, this deletion was also detected independently, is not unique to the B.1.1.7 variant, and can therefore often be misleading. Moreover, the absence of the $\mathrm{S}$ reaction in this assay may result from inhibition of this reaction, and therefore may not necessarily indicate the presence of the deletion. Variant B.1.1.7 was first reported in the UK on September 2020 and by December 2020 became the dominant strain in the country (2). Its increased infectivity led to its rapid spread, with severe consequences on public health and global economy (4). Likewise, from its first detection in Israel on December 23, this variant now comprises over 90\% of the positive cases (O. Erster and N. Zuckerman, Unpublished data).

An additional SC-2 VOC is the B.1.351 variant, which contains both B.1.351-unique mutations and mutations that are present in other notable VOC, such as the SGF deletion in the nsp6 gene, and the N501Y substitution in the spike gene that is identified also in the B1.1.7 (5). Like variant B.1.1.7, this variant was found to be more infectious than the WT strain. In vitro studies also show that it has increased resistance to serum of recovered and vaccinated patients, thereby posing a serious threat on the efficacy of current vaccination campaigns (6-8).

The emergence of these two variants, as well as other recently emerging SC-2 strains, necessitates constant improvement of the diagnostic tools used to combat the COVID-19 pandemic. In addition to performing a rapid, sensitive and specific detection of the viral RNA, diagnostic tests are now required to differentiate between circulating strains to provide valuable epidemiological data for policy decision 
medRxiv preprint doi: https://doi.org/10.1101/2021.05.19.21257439; this version posted May 22, 2021. The copyright holder for this preprint (which was not certified by peer review) is the author/funder, who has granted medRxiv a license to display the preprint in perpetuity. It is made available under a CC-BY-NC-ND 4.0 International license .

making. Commercial assays developed recently (, http://www.kogene.co.kr/eng/sub/product/covid-19/) detect specific key mutations. However, recent studies showed that in spite of sharing such mutations, variants might differ in their antibody resistance capacity, prompting development of variant specific assays $[5,9]$. These findings highlight the need to determine the identity of circulating strains, not only specific mutations. By designing a multiplex PCR assay that positively detects the presence of unique mutations that are strongly associated with variants B.1.1.7 and B.1.351, rapid, economical high throughput screening can be performed, enabling robust and specific identification of these variants in SC-2 positive clinical samples.

In this report, we describe a differential RT-qPCR assay that detects the presence of mutations strongly associated with variants B.1.1.7 and B.1.351. We demonstrate that implementation of this novel multiplex assay allows a sensitive and specific detection of SC-2 RNA, with the advantage of variant differentiation in a single assay.

\section{MATERIALS AND METHODS}

\section{Design of VOC-specific $\mathrm{qPCR}$ reactions}

Analysis of SC-2 sequences and primer simulations were performed using the Geneious software package (https://www.geneious.com/) and the NCBI BLAST analysis tools (https://blast.ncbi.nlm.nih.gov/). SC-2 sequences were obtained from GISAID initiative website (https://www.gisaid.org/) and Analyzed using the Geneious software. All primer and probe sequences are detailed in Table 1.

\section{Processing of SC-2 clinical samples}

Nasopharyngeal swab samples suspected to contain SC-2 in viral transport media (VTM) were inactivated by heating at $70^{\circ} \mathrm{C}$ for 30 minutes, or, if intended to be used for culturing, inactivated by addition of $200 \mu l$ lysis buffer (Zymo research, https://www.zymoresearch.com/products/dna-rna-lysis-buffer ) to $200 \mu$ l VTM.. Total RNA extraction was performed with either the Roche MagNA pure 96 system (https://lifescience.roche.com/), or the PSS MagLEAD instrument (http://www.pss.co.jp/english/). The eluted RNA was stored at $-80^{\circ} \mathrm{C}$ for further use, or used immediately thereafter for the PCR test. 
medRxiv preprint doi: https://doi.org/10.1101/2021.05.19.21257439; this version posted May 22, 2021. The copyright holder for this preprint (which was not certified by peer review) is the author/funder, who has granted medRxiv a license to display the preprint in perpetuity. It is made available under a CC-BY-NC-ND 4.0 International license .

\section{Design and synthesis of In vitro transcribed standard RNA segments}

In order to establish the analytical Limit of Detection (LOD) and obtain standard controls for WT and mutant target sequences, genomic regions including the $E, S_{242}, S_{R B D}, N$ and RNASE P were amplified using primers that contain the T7 promoter minimal sequence (Table 2) with the MyTaq One-step RT-PCR kit. The resulting PCR products were transcribed In vitro to RNA using the T7 Megascript kit according to the manufacturer's instructions (Thermo Fisher, https://www.thermofisher.com/). The In-vitro transcribed RNA was purified and its concentration was determined using Nanodrop spectrophotometer and stored at $-80^{\circ} \mathrm{C}$.

\section{RT-qPCR}

RT-qPCR mix was prepared with the Meridian (formerly Bioline) SensiFast one-step mix (https://www.bioline.com/). Initial optimization was performed by setting an annealing temperature gradient. Following optimization of the reaction conditions, the final mix concentration was determined. The reaction mix was assembled as follows: SensiFast Probe Lo-ROX One-Step: 12.5 $\mu$ l, E Sarbeco-F1b: 400nM, E-Sarbeco-R: 400nM, E-Sarbeco Probe: 200nM, 21257VOC Fwd: 750nM, CDC N1 Rev: 750nM, CDC N1 probe: 300nM, 22201B SA Fwd: 600nM, 22238 SA Rev: 800nM, 22230 probe: 300nM, RNASE P Fwd: 300nM, RNASE P Rev: 300nM, RNASE P probe: 200nM, RT Enzyme: 0.2 $\mu \mathrm{l}$, RNAse inhibitor: $0.2 \mu l$, $\mathrm{ddH}_{2} \mathrm{O}$ - to a final volume of $1 \mu \mathrm{l}$.

The amplification was performed in Bio-Rad CFX96 thermal cycler (https://www.bio-rad.com) using the following conditions:

(a) $45^{\circ} \mathrm{C}$ for $10^{\prime}$, (b) $95^{\circ} \mathrm{C}$ for $2^{\prime}: 20^{\prime \prime}, 45 X\left[\right.$ (C) $95^{\circ} \mathrm{C}$ for $4^{\prime \prime}$, (d) $62.2^{\circ} \mathrm{C}$ for $\left.28^{\prime \prime}\right]$. Fluorescence was recorder at each cycle during the annealing and extension step $\left(62.2^{\circ} \mathrm{C}\right.$ for $\left.28^{\prime \prime}\right)$. The reaction data were analyzed using the Bio-Rad CFX Maestro software.

\section{Sanger Sequencing of suspected samples}

In order to identify mutations of the variants of interest in suspected samples, several rapid sequencing reactions of the Spike gene were designed and implemented. This enabled the first identification of the B.1.1.7-related mutations 69-70Del, 144Del, N501Y, S982A and D1118H, and B.1.351-related mutations D215G, 242Del K417N, N501Y and E484K. Primer sets for the rapid sequencing reactions of the Spike and Nucleocapside $(\mathrm{N})$ genes are detailed in Table $\mathbf{2}$. 
medRxiv preprint doi: https://doi.org/10.1101/2021.05.19.21257439; this version posted May 22, 2021. The copyright holder for this preprint (which was not certified by peer review) is the author/funder, who has granted medRxiv a license to display the preprint in perpetuity. It is made available under a CC-BY-NC-ND 4.0 International license .

5

Endpoint PCR reactions were performed with MyTaq One-step RT-PCR kit (Meridian, https://www.bioline.com/mytaq-mix.html) according to the manufacturer's instructions. Resulting PCR products were analyzed using agarose gel electrophoresis and sequenced using the ABI 3500 Bioanalyzer.

\section{Next Generation Whole genome sequencing of clinical samples}

COVID-seq kit was used for library preparation as per manufacturer's instructions (Illumina, https://www.illumina.com/). Library validation and mean fragment size was determined by TapeStation 4200 via DNA HS D1000 kit (Agilent, https://www.agilent.com/). Libraries were pooled, denatured and diluted to 10pM and sequenced on NovaSeq (Illumina).

\section{Bioinformatic and phylogenetic analysis}

Fastq files underwent quality control using FastQC (www.bioinformatics.babraham.ac.uk/ projects/fastqc/) and MultiQC [10] and low-quality sequences were filtered using trimmomatic [PMID: 24695404]. Mapping to SARS-CoV-2 genome (NC_045512.2) was performed with BWA mem [PMID: 19451168]. SAMtools suite [PMID: 19505943] was used to filter unmapped reads, sort and index bam files. Consensus fasta sequences were constructed for each sample using iVar (https://andersenlab.github.io/ivar/html/manualpage.html), with Ns inserted in positions with sequencing depth lower than five. Sequences were aligned with the SARS-CoV-2 reference sequence (NC_045512.2) with MAFFT [11] and mutation analysis was done with a custom $\mathrm{R}$ code using Bioconductor package seqinr [citation info in: https://cran.r-project.org/web/packages/seqinr/citation.html].

\section{RESULTS}

\section{Development of differential COV19 VOC RT-qPCR}

Analysis of mutations characteristic of variants B.1.1.7 and B.1.351 showed that some of them were mutual to both, like the SGF deletion in nsp6 (positions 11285-11294 in sequence NC_045512), or the N501Y substitution in the spike protein gene (nucleotide position 23,094 in sequence NC_045512). Others, such as the 69-70 deletion and N501Y substitution, developed independently and were detected in samples not classified as variant B.1.1.7 (Supplementary Figure S1). On the other hand, the N gene D3L mutation is strongly associated with variant B.1.1.7 and is not associated with other currently dominant variants. Likewise, the D215G mutation and the S gene 242-244 deletion are strongly 
medRxiv preprint doi: https://doi.org/10.1101/2021.05.19.21257439; this version posted May 22, 2021. The copyright holder for this preprint (which was not certified by peer review) is the author/funder, who has granted medRxiv a license to display the preprint in perpetuity. It is made available under a CC-BY-NC-ND 4.0 International license .

6

associated with variant B.1.351 and were not identified in other variants thus far (Supplementary Figure S2.). Therefore, these two regions were selected for the multiplex reactions design.

\section{Design of variant B.1.1.7 specific reaction}

The 5'p region of variant B.1.1.7 SC-2 N gene contains a complete codon substitution, translated into D3L a.a. substitution. Additionally, there is a single " $A$ " deletion in this region, 5 bases upstream to the $\mathrm{N}$ gene start codon (Figure 1). A selective primer was designed accordingly, to specifically detect the mutated variant. The reverse primer and the probe were based on the CDC N1 reaction (https://www.cdc.gov/coronavirus/2019-ncov/lab/rt-pcr-panel-primer-probes.html), as detailed in Table 1. The B.1.1.7-specific reaction was combined with an inclusive reaction based on the E-sarbeco qPCR described by Corman et al. (12), with minor modifications, as detailed in Table 1. This reaction was designed to detect all known CoV19 clades, thereby serving as an indicator for the presence of SC-2 RNA in the examined sample. The combined assay was then tested using WT and sequence-verified samples identified as belonging to lineage B.1.1.7 (Figure 1). All samples identified as belonging to clade B.1.1.7 were detected using the new multiplex assay. WT samples were either negative for the $\mathrm{N}$ reaction, or gave a very weak signal, approximately 10-15 cycles apart from the E reaction signal (Figure 1). This reaction was termed $\mathrm{N}$ gene $\mathrm{D} 3 \mathrm{~L}$ reaction.

\section{Design of variant B.1.351 specific reaction}

This variant contains two unique mutations in the spike gene, D215G and a deletion at amino acid position 242 (nucleotide positions 22281 and 22289 in sequence NC_045512). A specific reaction was developed, based on these mutations, which detects samples of lineage B.1.351, as described. The forward primer was designed to anneal to the substituted nucleotide at its 3'p end. In order to increase the primer selectivity, a mismatched base was inserted 10 b.p. downstream to the $5^{\prime} p$ end. The reverse primer was designed to complement the region of the 242-244 deletion (Figure 2). This reaction resulted in a negative, or a very weak signal, when testing WT samples, and a clear signal when testing samples previously sequenced and identified as belonging to the B.1.351 clade (Figure 2). This reaction was then termed $S_{242}$ reaction.

\section{Generation and evaluation of a multiplex SC-2 VOC reaction}


medRxiv preprint doi: https://doi.org/10.1101/2021.05.19.21257439; this version posted May 22, 2021. The copyright holder for this preprint (which was not certified by peer review) is the author/funder, who has granted medRxiv a license to display the preprint in perpetuity. It is made available under a CC-BY-NC-ND 4.0 International license .

The two reactions were combined with the $E$ target reaction and a reaction targeting the RNAse $P$ gene (https://www.cdc.gov/coronavirus/2019-ncov/lab/rt-pcr-panel-primer-probes.html) that serves as an endogenous control for RNA extraction. The multiplex reaction was then tested for sensitivity using serial dilutions of in vitro-transcribed RNA containing the target sequences of all four reactions. As detailed in Supplementary Figure S3, the calculated analytical limit of detection for the three viral targets was as follows: 29 copies per reaction for the E-sarbeco reaction, 26 copies per reaction for the $N_{D 3 L}$, and 39 copies per reaction for the $S_{242}$ reactions. This sensitivity was accomplished using a reaction that takes less than 70 minutes, thereby shortening the entire time from sample to answer.

Specificity test performed with a panel of respiratory pathogens showed no cross-detection of pathogens other than SC-2, except for SARS CoV-1 (SC-1), which was detected, as expected, by the E-sarbeco reaction. Nucleic acid samples of the following pathogens were tested: Chlamydia pneumonia, Rhinovirus, Influenza A, Influenza B, Swine influenza, RSV A, RSV B, Parainfluenza 3, HMPV, Adenovirus, CoV OC43, CoV 229E, CoV HKU1, CoV NL63, SARS-1 and MERS CoV.

The multiplex SC-2 VOC assay was then tested using sequence-verified samples, and successfully detected all samples in full agreement with the sequencing results, thereby confirming the accuracy of the assay. Notably, in samples with high viral RNA concentration, a weak signal of $S_{242}$ variant was observed. However, the Cq difference between the E gene target signal and the $\mathrm{S}_{242}$ reaction clearly indicated that the signal does not reflect the presence of the D215G and 242-244 deletion mutations, but rather a low-affinity binding of the primers to the RNA.

\section{Confirmatory Sequencing of suspected samples}

The first three samples suspected as variant B.1.1.7 (numbered 5824, 6021 and 7075) were negative for the $S$ reaction in the Thermo-Fisher SARS-COV-2 test, were subjected to further examination in the Israel Central Virology Laboratory (CVL). Focused Sanger sequencing of the $S$ gene region of samples 5824 and 6021 showed the presence of the $69-70$ deletion, but the B.1.1.7 variant-associated mutations $144 \mathrm{del}$ and N501Y substitution were absent. They both contained, however, a unique substitution - N439K, which is not associated with the B.1.1.7 variant (Supplementary figure S4). Sanger sequencing of the spike gene region from sample 7075, contained the following mutations, all of which characteristic of the B.1.1.7 variant: 69-70 deletion, 144 deletion, N501Y, S982A and D1118H (Supplementary figure S5). Subsequent complete genome analysis via next generation sequencing (NGS) of that sample confirmed 
medRxiv preprint doi: https://doi.org/10.1101/2021.05.19.21257439; this version posted May 22, 2021. The copyright holder for this preprint (which was not certified by peer review) is the author/funder, who has granted medRxiv a license to display the preprint in perpetuity. It is made available under a CC-BY-NC-ND 4.0 International license .

the presence of all the defining mutations of the B.1.1.7 variant, thereby corroborating the initial results of the Sanger sequencing. This was the first known case of the B.1.1.7 variant in Israel.

Samples suspected as the B.1.351 variant were initially examined by Sanger sequencing of two regions of the spike protein: the 242-244 deletion, which is unique to this variant, and the receptor binding domain (RBD, nucleotide positions 22,493-23,218). Out of 20 suspected samples, four contained the following mutations in the spike gene: D215G, 242-244 deletion, K417N, E484K, and N501Y, all associated with the B.1.351 variant (Supplementary figure S6). Subsequent complete genome analysis via NGS confirmed the presence of the B.1.351 defining mutations.

To confirm the accuracy of the multiplex reaction, complete genome sequencing of 122 clinical samples was performed, with complete agreement with the qPCR results. For variant B.1.1.7, over 1,000 samples were examined by both the new qPCR assay and by whole genome sequencing, with complete match. These results demonstrate that the new multiplex assay described herein can be used as a rapid and reliable approach for primary classification of SC-2 B.1.1.7 and B.1.351 variants.

\section{DISCUSSION}

The emergence of new, more contagious and potentially antigenically different SC-2 lineages pose an urgent need to adjust rapid detection methods to meet public health related needs. To meet these needs, we developed a multiplex RT-qPCR assay that can distinguish between three SC-2 lineages. The assay is rapid ( 1 hour PCR assay time) and is suitable for high throughput rapid screening. This is in contrast to Sanger sequencing or NGS, which are more informative, but are far more expensive, take significantly more time, and cannot be scaled up easily. Since the beginning of the COVID-19 pandemic, several rapid tests detecting the presence of SC-2 RNA or proteins were implemented in wide scale testing (13). However, the capacity to distinguish between different lineages in a time scale of hours is currently possible only using qPCR.

SC-2 variant B.1.1.7 contains numerous synonymous and non-synonymous mutations, of which the Spike gene mutations 69-70del, $\mathrm{N} 501 \mathrm{Y}$, and $\mathrm{P} 681 \mathrm{H}$ received most attention due to their potential effect on virus infectivity (14-15). For diagnostic purposes, however, the N501Y mutation is not variant-specific, as it was identified in several variants other than variant B.1.1.7, such as B.1.351 and the P.1 variant first discovered in Brazil (16). The D3L substitution in the $\mathrm{N}$ gene used in our assay is specific to variant B.1.1.7 and was not reported in other major SC-2 lineages. Although this mutation can occur independently from other characteristic mutations, such as N501Y, its presence strongly suggests that the examined sample 
medRxiv preprint doi: https://doi.org/10.1101/2021.05.19.21257439; this version posted May 22, 2021. The copyright holder for this preprint (which was not certified by peer review) is the author/funder, who has granted medRxiv a license to display the preprint in perpetuity.

It is made available under a CC-BY-NC-ND 4.0 International license .

9

is the B.1.1.7 variant. Likewise, the reaction that identifies the variant B.1.351 targets mutations that are strongly associated with this variant: D215G and the triple deletion of amino acids 242-244 (Supplementary Figure S4). The combinations of these two reactions therefore provides a reliable tool to identify each of these two variants with high confidence. In order to increase the range of the new assay, the SC-2 inclusive reaction targeting the E gene (12) was combined, thereby enabling detection of the viral RNA independently of the strain examined.

A few commercial kits partially address the detection of these SC-2 variants, but they target general mutations, such as N501Y and E484K in the spike protein, and not variant-specific mutations, such as the N protein D3L substitution or the spike protein 242-244 deletion (https://www.seegene.com/assays/rp, http://www.kogene.co.kr/eng/sub/product/covid-19.asp).

The emergence of novel SC-2 variants with increased infectivity and increased resistance to current vaccines may significantly impair global large-scale detection and vaccination efforts (17). Moreover, it has been shown that different variants having some identical mutation in the spike coding sequence still have different infectivity and vaccine resistance characteristics due to their different set of additional mutations [5,9, Mandelboim M., unpublished data]. As a result, the pressing need to improve detection methods accordingly requires constant adjustments. Such a diagnostic tests should not only detect the presence of the viral RNA with high specificity and sensitivity, but also provide information on variant identity. Additional consideration is the relatively high cost of commercial kits, and the need to perform complex interpretation of the results, to determine the possible sample identity. The execution and analysis of the assay described herein are simple, and relatively inexpensive, compared with current commercial kits. Implementation of molecular assays such as our multiplex qPCR assay will improve SC2 diagnosis and contribute to the ongoing efforts to contain the COVID-19 pandemic.

\section{ACKNOWLEDGEMENTS}

The authors wish to thank the members of the Israel Central Virology Laboratory for their valuable help in this work.

\section{CONFLICT OF INTERESTS}

The authors declare no conflict of interests. 
medRxiv preprint doi: https://doi.org/10.1101/2021.05.19.21257439; this version posted May 22, 2021. The copyright holder for this preprint (which was not certified by peer review) is the author/funder, who has granted medRxiv a license to display the preprint in perpetuity. It is made available under a CC-BY-NC-ND 4.0 International license .

\section{Figure Legends}

Figure 1. Design of variant B.1.1.7-specific reaction. A specific primer was designed based on the single nucleotide insertion and the codon substitution in the 5'p of the SC-2 N gene, both circled and highlighted. The specific "UK VOC" reaction was combined with an inclusive E-sarbeco reaction (Corman et al. 2020) that detects all SC-2 variants. The presence of the B.1.1.7 RNA in the assay results in two clear amplification curves (A). A sample containing a non- B.1.1.7 variant sequence results in a faint amplification, with a Cq different larger than eight between the $E$ and the $N$ curves (B), or a negative signal for the $\mathrm{N}$ reaction $(\mathrm{C})$.

Figure 2. Design of variant B.1.351-specific reaction. Two primers were designed, to specifically complement the sequences containing the D215G mutation, and the 242-244 deletion. The resulting reaction gives a clear signal of the $S_{242}$ reaction with sample belonging to clade B.1.351 (A), and a negative, or a faint signal with a WT sample (B). The inclusive E-sarbeco reaction detects the presence of both the WT and clade B.1.351 samples. 
medRxiv preprint doi: https://doi.org/10.1101/2021.05.19.21257439; this version posted May 22, 2021. The copyright holder for this preprint (which was not certified by peer review) is the author/funder, who has granted medRxiv a license to display the preprint in perpetuity.

It is made available under a CC-BY-NC-ND 4.0 International license .

11

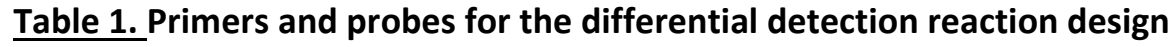

\begin{tabular}{|c|c|c|c|}
\hline Targeted region & Name & Sequence $5^{\prime}->3^{\prime}$ and modifications & Source \\
\hline SC-2 E gene & E-sarbeco R2 & ATATTGCAGCAGTACGCACACA & Corman et al. 2020 \\
\hline SC-2 E gene & E-sarbeco probe & TXRed-ACACTAGCCATCCTTACTGCGCTTCG-BHQ2 & Corman et al. 2020 \\
\hline $\mathrm{N}_{\mathrm{D} 3 \mathrm{~L}}$ & 21257VOC Fwd & TAAACGAACAAACTAAATGTCTCTA & This study \\
\hline $\mathrm{N}_{\mathrm{D} 3 \mathrm{~L}}$ & CDC N1 probe & HEX-ACCCCGCATTACGTTTGGTGGACC-BHQ1 & $\mathrm{CDC}^{2}$ \\
\hline $\mathrm{S}_{\mathrm{D} 215 \mathrm{G}}$ and $\mathrm{S}_{242 \mathrm{Del}}$ & 22201B SA Fwd & CGCCTATTATTTTAATTGCGTGG & This study \\
\hline $\mathrm{S}_{\mathrm{D} 215 \mathrm{G}}$ and $\mathrm{S}_{242 \mathrm{Del}}$ & 22238 SA Rev & CAAATAACTTCTATGTAAAGTTTGAAAC & This study \\
\hline $\mathrm{S}_{\mathrm{D} 215 \mathrm{G}}$ and $\mathrm{S}_{242 \mathrm{Del}}$ & 22230_probe & CAGGGTTTTTCGGCTTTAGAACCATTGG & This study \\
\hline
\end{tabular}

${ }^{1}$ The original sequence was modified to improve compatibility in the multiplex reaction.

${ }^{2}$ https://www.cdc.gov/coronavirus/2019-ncov/lab/rt-pcr-panel-primer-probes.html

Table 2. Cloning reactions design

\begin{tabular}{|c|c|c|c|}
\hline Mutations within product & Fwd primer $5^{\prime}->3^{\prime}$ & Rev primer $5^{\prime}->3^{\prime}$ & Product size \\
\hline 69-70Del, 144Del, D215G, 242Del & TTAGATTCGAAGACCCAGTCCCTAC & GTTTCTGAGAGAGGGTCAAGTGCAC & \\
\hline Spike & CoV19 22509 & CoV19 23233 & $725 b p$ \\
\hline K417N, E484K, N501Y & GGAATCTATCAAACTTCTAACTTTAGAG & AGAACACCTGTGCCTGTTAAACCATTG & \\
\hline S982A, D1118H & GATTGCTCAATACACTTCTGCAC & TGAGGGAAGGACATAAGATGATAG & \\
\hline $\mathrm{N}$ & nCoV $28225 \mathrm{~F}$ & COV19 29297 & $1090 \mathrm{bp}$ \\
\hline D3L & GAAGACTTTTTAGAGTATCATGAC & GGATCTTTGTCATCCAATTTGATG & \\
\hline
\end{tabular}


medRxiv preprint doi: https://doi.org/10.1101/2021.05.19.21257439; this version posted May 22, 2021. The copyright holder for this preprint (which was not certified by peer review) is the author/funder, who has granted medRxiv a license to display the preprint in perpetuity. It is made available under a CC-BY-NC-ND 4.0 International license .

\section{Reference}

1. Davies NG, Abbott S, Barnard RC, Jarvis Cl, Kucharski AJ, Munday JD, Pearson CAB, Russell TW, Tully DC, Washburne AD, Wenseleers T, Gimma A, Waites W, Wong KLM, van Zandvoort K, Silverman JD; CMMID COVID-19 Working Group; COVID-19 Genomics UK (COG-UK) Consortium, Diaz-Ordaz K, Keogh R, Eggo RM, Funk S, Jit M, Atkins KE, Edmunds WJ. Estimated transmissibility and impact of SARS-CoV-2 lineage B.1.1.7 in England. Science. eabg3055. doi: 10.1126/science.abg3055.DOI: 10.1126/science.abg3055

2. Volz E, Mishra S, Chand M, Barrett JC, Johnson R, Geidelberg L, Hinsley WR, Laydon DJ, Dabrera G, O'Toole Á, Amato R, Ragonnet-Cronin M, Harrison I, Jackson B, Ariani CV, Boyd O, Loman NJ, McCrone JT, Gonçalves S, Jorgensen D, Myers R, Hill V, Jackson DK, Gaythorpe K, Groves N, Sillitoe J, Kwiatkowski DP; COVID-19 Genomics UK (COG-UK) consortium, Flaxman S, Ratmann O, Bhatt S, Hopkins S, Gandy A, Rambaut A, Ferguson NM. Assessing transmissibility of SARS-CoV-2 lineage B.1.1.7 in England. Nature. 2021 May;593(7858):266-269. doi: 10.1038/s41586-021-03470-x.

3. Davies NG, Jarvis Cl; CMMID COVID-19 Working Group, Edmunds WJ, Jewell NP, Diaz-Ordaz K, Keogh RH. Increased mortality in community-tested cases of SARS-CoV-2 lineage B.1.1.7. Nature. 2021 May;593(7858):270-274. doi: 10.1038/s41586-021-03426-1.

4. Grint DJ, Wing K, Williamson E, McDonald HI, Bhaskaran K, Evans D, Evans SJ, Walker AJ, Hickman G, Nightingale E, Schultze A, Rentsch CT, Bates C, Cockburn J, Curtis HJ, Morton CE, Bacon S, Davy S, Wong AY, Mehrkar A, Tomlinson L, Douglas IJ, Mathur R, Blomquist P, MacKenna B, Ingelsby P, Croker R, Parry J, Hester F, Harper S, DeVito NJ, Hulme W, Tazare J, Goldacre B, Smeeth L, Eggo RM. Case fatality risk of the SARS-CoV-2 variant of concern B.1.1.7 in England, 16 November to 5 February. Euro Surveill. doi: 10.2807/1560-7917.ES.2021.26.11.2100256

5. Wang P, Nair MS, Liu L, Iketani S, Luo Y, Guo Y, Wang M, Yu J, Zhang B, Kwong PD, Graham BS, Mascola JR, Chang JY, Yin MT, Sobieszczyk M, Kyratsous CA, Shapiro L, Sheng Z, Huang Y, Ho DD. Antibody resistance of SARS-CoV-2 variants B.1.351 and B.1.1.7. Nature. 2021 May;593(7857):130135. doi: 10.1038/s41586-021-03398-2..

6. Tegally, Wilkinson, Giovanetti, Iranzadeh et al.. Emergence and rapid spread of a new severe acute respiratory syndrome-related coronavirus 2 (SARS-CoV-2) lineage with multiple spike mutations in South Africa. medRxiv preprint doi: ttps://doi.org/10.1101/2020.12.21.2024864

7. Garcia-Beltran WF, Lam EC, St Denis K, Nitido AD, Garcia ZH, Hauser BM, Feldman J, Pavlovic MN, Gregory DJ, Poznansky MC, Sigal A, Schmidt AG, lafrate AJ, Naranbhai V, Balazs AB. Multiple SARS- 
medRxiv preprint doi: https://doi.org/10.1101/2021.05.19.21257439; this version posted May 22, 2021. The copyright holder for this preprint (which was not certified by peer review) is the author/funder, who has granted medRxiv a license to display the preprint in perpetuity. It is made available under a CC-BY-NC-ND 4.0 International license .

CoV-2 variants escape neutralization by vaccine-induced humoral immunity. Cell. $2021 \mathrm{Apr}$ 29;184(9):2372-2383.e9. doi: 10.1016/j.cell.2021.03.013.

8. Cele S, Gazy I, Jackson L, Hwa SH, Tegally H, Lustig G, Giandhari J, Pillay S, Wilkinson E, Naidoo Y, Karim F, Ganga Y, Khan K, Bernstein M, Balazs AB, Gosnell BI, Hanekom W, Moosa MS; Network for Genomic Surveillance in South Africa; COMMIT-KZN Team, Lessells RJ, de Oliveira T, Sigal A. Escape of SARS-CoV-2 501Y.V2 from neutralization by convalescent plasma. Nature. 2021 May;593(7857):142-146. doi: 10.1038/s41586-021-03471-w.

9. Lustig Y, Nemet I, Kliker L, Zuckerman N, Yishai R, Alroy-Preis S, Mendelson E, Mandelboim M. Neutralizing Response against Variants after SARS-CoV-2 Infection and One Dose of BNT162b2. N Engl J Med. 2021 Apr 7:NEJMc2104036. doi: 10.1056/NEJMc2104036.

10. Ewels $P$, Magnusson M, Lundin S, Käller M. MultiQC: summarize analysis results for multiple tools and samples in a single report. Bioinformatics. 2016 Oct 1;32(19):3047-8. doi: 10.1093/bioinformatics/btw354.

11. Katoh K, Standley DM. MAFFT multiple sequence alignment software version 7: improvements in performance and usability. Mol Biol Evol. 2013 Apr;30(4):772-80. doi: 10.1093/molbev/mst010.

12. Corman VM, Eckerle I, Bleicker T, Zaki A, Landt O, Eschbach-Bludau M, van Boheemen S, Gopal R, Ballhause M, Bestebroer TM, Muth D, Müller MA, Drexler JF, Zambon M, Osterhaus AD, Fouchier RM, Drosten C. Detection of a novel human coronavirus by real-time reverse-transcription polymerase chain reaction. Euro Surveill. 2012 Sep 27;17(39):20285. doi: 10.2807/ese.17.39.20285-en

13. Dinnes J, Deeks JJ, Berhane S, Taylor M, Adriano A, Davenport C, Dittrich S, Emperador D, Takwoingi Y, Cunningham J, Beese S, Domen J, Dretzke J, Ferrante di Ruffano L, Harris IM, Price MJ, Taylor-Phillips S, Hooft L, Leeflang MM, McInnes MD, Spijker R, Van den Bruel A; Cochrane COVID-19 Diagnostic Test Accuracy Group. Rapid, point-of-care antigen and molecular-based tests for diagnosis of SARS-CoV-2 infection. Cochrane Database Syst Rev. 2021 Mar 24;3(3):CD013705. doi: 10.1002/14651858.CD013705.pub2

14. Hussain M, Shabbir S, Amanullah A, Raza F, Imdad MJ, Zahid S. Immunoinformatic analysis of structural and epitope variations in the spike and Orf8 proteins of SARS-CoV-2/B.1.1.7. J Med Virol. 2021 Mar 11. doi: 10.1002/jmv.26931.

15. Singh J, Samal J, Kumar V, Sharma J, Agrawal U, Ehtesham NZ, Sundar D, Rahman SA, Hira S, Hasnain SE. Structure-Function Analyses of New SARS-CoV-2 Variants B.1.1.7, B.1.351 and B.1.1.28.1: Clinical, Diagnostic, Therapeutic and Public Health Implications. Viruses. 2021 Mar 9;13(3):439. doi: 10.3390/v13030439. 
medRxiv preprint doi: https://doi.org/10.1101/2021.05.19.21257439; this version posted May 22, 2021. The copyright holder for this preprint (which was not certified by peer review) is the author/funder, who has granted medRxiv a license to display the preprint in perpetuity. It is made available under a CC-BY-NC-ND 4.0 International license.

14

16. Sabino EC, Buss LF, Carvalho MPS, Prete CA Jr, Crispim MAE, Fraiji NA, Pereira RHM, Parag KV, da Silva Peixoto P, Kraemer MUG, Oikawa MK, Salomon T, Cucunuba ZM, Castro MC, de Souza Santos AA, Nascimento VH, Pereira HS, Ferguson NM, Pybus OG, Kucharski A, Busch MP, Dye C, Faria NR. Resurgence of COVID-19 in Manaus, Brazil, despite high seroprevalence. Lancet. 2021 Feb 6;397(10273):452-455. doi: 10.1016/S0140-6736(21)00183-5

17. Case JB, Winkler ES, Errico JM, Diamond MS. On the road to ending the COVID-19 pandemic: Are we there yet? Virology. 2021 May;557:70-85. doi: 10.1016/j.virol.2021.02.003 


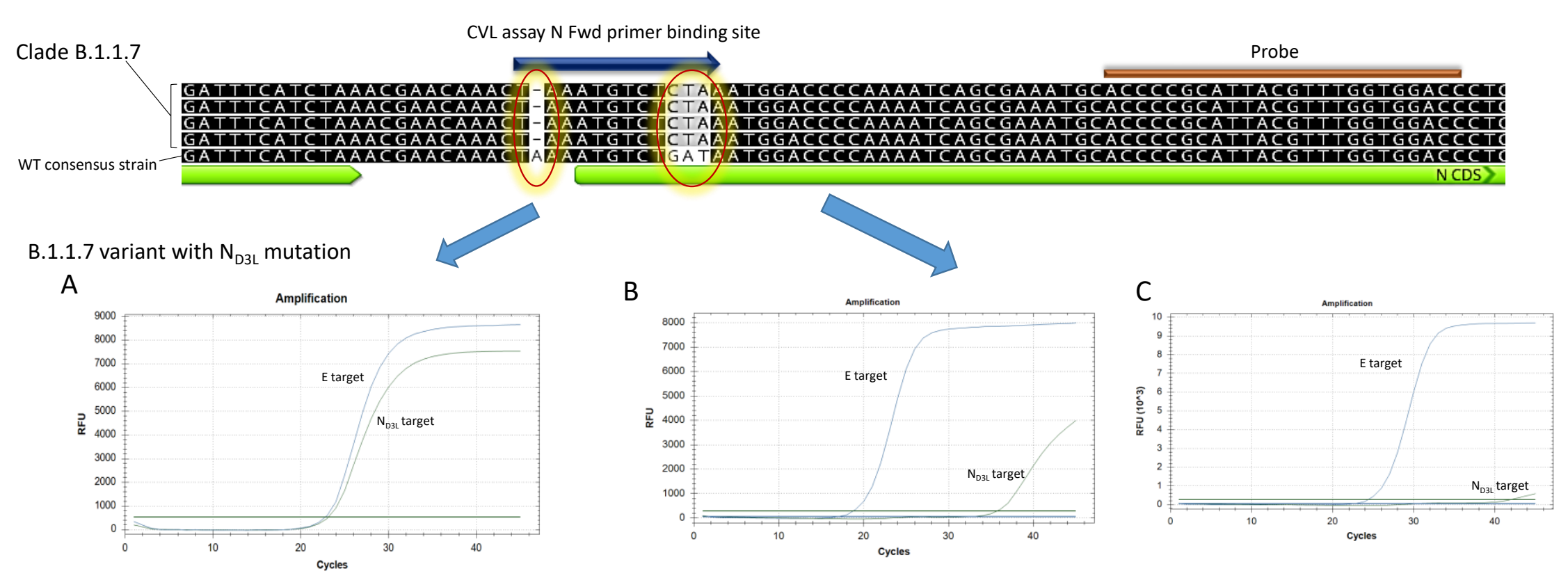

Figure 1. Design of variant B.1.1.7-specific reaction. A specific primer was designed based on the single nucleotide insertion and the codon substitution in the 5'p of the SC-2 N gene, both circled and highlighted. The specific "UK VOC" reaction was combined with an inclusive E-sarbeco reaction (Corman et al. 2020) that detects all SC-2 variants. The presence of the B.1.1.7 RNA in the assay results in two clear amplification curves (A). A sample containing a non- B.1.1.7 variant sequence results in a faint amplification, with a Cq different larger than eight between the $E$ and the $\mathrm{N}$ curves (B), or a negative signal for the $\mathrm{N}$ reaction $(\mathrm{C})$. 


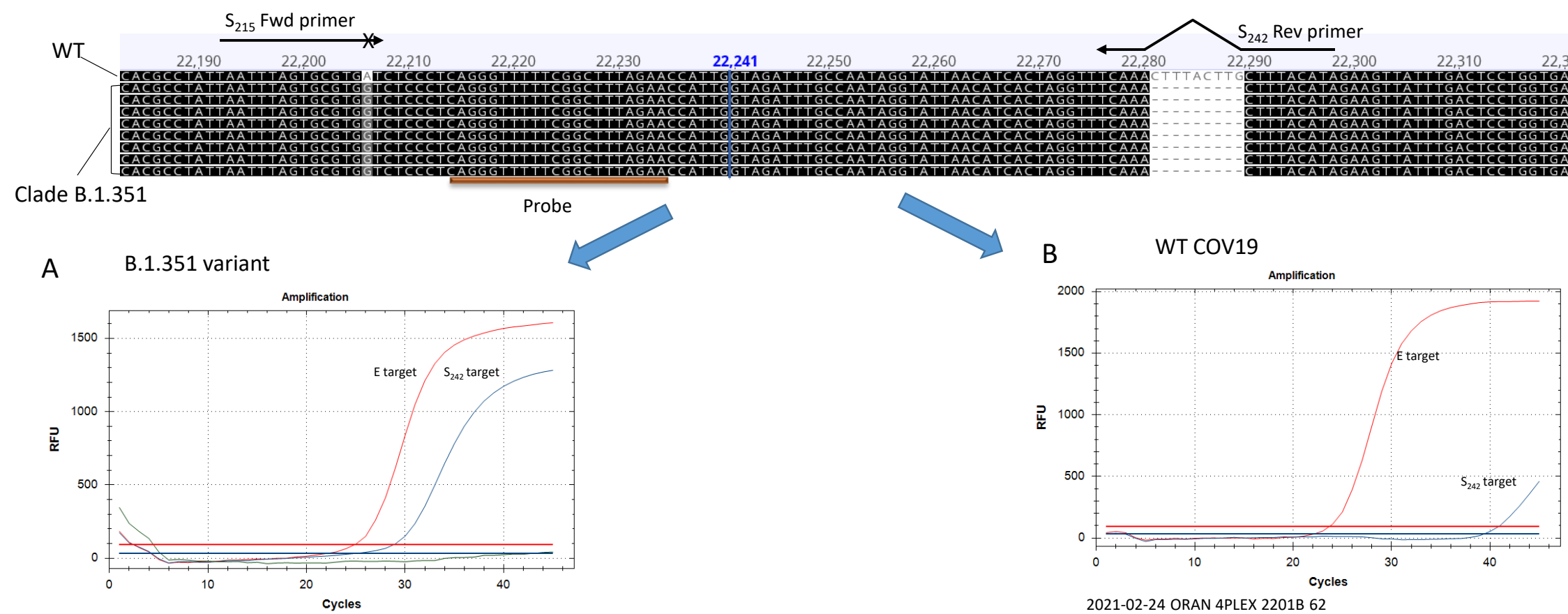

Figure 2. Design of variant B.1.351-specific reaction. Two primers were designed, to specifically complement the sequences containing the D215G mutation, and the 242-244 deletion. The resulting reaction gives a clear signal of the $\mathrm{S}_{242}$ reaction with sample belonging to clade B.1.351 (A), and a negative, or a faint signal with a WT sample (B). The inclusive E-sarbeco reaction detects the presence of both the WT and clade B.1.351 samples. 